\title{
Usefulness of Augmented Reality as a Tool to Support Online Learning
}

\author{
Ismail $^{1}$, Nur Iksan ${ }^{2}$, Siva Kumar Subramaniam ${ }^{3}$, Azmi Shawkat Abdulbaqie ${ }^{4}$, Salini Krishna Pillai ${ }^{5}$, Ismail \\ Yusuf Panessai ${ }^{6}$ \\ ${ }^{1}$ Universitas Ibnu Sina (1027087604), Batam, Indonesia \\ ${ }^{2}$ Lamintang Education \& Training (LET) Centre, Batam, Indonesia \\ ${ }^{3}$ Universiti Teknikal Malaysia Melaka, Malaysia \\ ${ }^{4}$ University of Anbar, Al Anbar, Iraq \\ ${ }^{5}$ Universiti Pendidikan Sultan Idris, Tanjung Malim, Malaysia \\ ${ }^{6}$ Universiti Pendidikan Sultan Idris, Tanjung Malim, Malaysia
}

\begin{tabular}{l} 
ARTICLE INFO \\
\hline Article history: \\
Received July 18, 2021 \\
Revised August 12, 2021 \\
Accepted August 28, 2021 \\
\hline
\end{tabular}

Keywords:

Augmented Reality;

Teaching and Learning;

Usability;

Usefulness

\begin{abstract}
The global crisis following the outbreak of the Covid-19 epidemic has had an impact on the teaching and learning process (PdP). The main problem with $\mathrm{PdP}$ during the Covid-19 epidemic was the limitation in conducting face-toface activities in the classroom. Therefore, a learning aid is needed to enable $\mathrm{PdP}$ to run optimally even though there is no face-to-face interaction between teachers and students. The research contribution is to highlight the application of Augmented Reality to support distance learning in the Covid-19 epidemic situation, specializing in Wood Carving Art for the subject of Visual Arts Education Form 4. The AR Wood Carving Art mobile application uses the ADDIE design model based on five phases, namely Analysis, Design, Development, Implementation, and Testing. The AR Wood Carving Art mobile application is evaluated based on its usefulness. The AR Wood Carving Art mobile application was evaluated among 27 students from 4 of SMK Pasir Gudang (Johor, Malaysia) and registered to Visual Arts. Based on the result, $80 \%$ of respondents strongly agree that the AR Wood Craving Art mobile application help respondents be more effective. It helps users to be more productive and giving ideas to users to be creative and innovative. One hundred percent of respondents strongly agree that the AR Wood Craving Art mobile application makes things that users want to achieve easier to do, and the AR Wood Craving Art mobile application does what users want. Eighty percent of respondents strongly agree that the AR Wood Craving Art application is useful and the application saves time when users use it. Therefore, the AR Wood Craving Art application is effectively used in learning which makes users more productive, creative, and innovative. In addition, the AR Wood Craving Art mobile application makes it easy for users to understand wood carving topics in visual arts subjects, and users can carry out educational and teaching activities like in a classroom.
\end{abstract}

This work is licensed under a Creative Commons Attribution-Share Alike 4.0

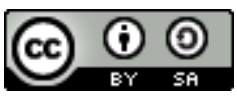

Ismail Yusuf Panessai,

Faculty of Art, Computing \& Industry Creative (FSKIK), Univerisiti Pendidikan Sultan Idris, Tanjong Malim, Perak 35900, Malaysia.

Email: ismailyusuf.panessai@yahoo.com

\section{INTRODUCTION}

Augmented Reality (AR) mobile applications in education are increasing rapidly along with the increasing use of mobile AR due to advances in mobile technology [1][2][3]. Augmented Reality is more accessible to Generation Z. As is well known, Generation Z students prefer to use technology rather than faceto-face discussions, especially in education. To adapt to the current trend, teachers as knowledge transmitters need to increase their knowledge in technology and produce creative content. The use of technology in the 
learning process cannot be separated but needs to be used wisely so as not to harm [4][5]. Keeping up with educational developments in the world should be the goal of education in this modern world and not rely on the knowledge and statistical systems [6][7][8]. Likewise, students are expected to use technology to support their success in academics [9].

Most schools have been faced with a sudden and unprepared shift to online teaching to respond to the need and to continue teaching and learning activities when social distancing measures are implemented. It is happened due to unawareness of covid-19 and took unpredictable time to cure purely (transition time). The transition can be decomposed into several interconnected dimensions that impact the feasibility and the quality of the distance learning provided [10][11].

Students need to have technology access as the primary indicator of online learning readiness. Since students are also learning independently, instructors may also need more time to design their delivery of content effectively as students will inevitably face technical and adaptation difficulties.

Teachers as intermediaries in delivering teaching and students as recipients of learning content need to have a paradigm shift to accept new scenarios in order to be digitally literate. Therefore, to adapt to the new environment, providing structured content in writing is impractical [1][3]. In other words, one of the appropriate presentation tools to deliver a syllabus is 3-Dimensional. The ability to understand 3-Dimensional helps students to visualize objects realistically and improve imaginary skills [9]. In addition, the global crisis after the outbreak of the Covid-19 epidemic reminded the readiness of the teaching and learning process (PdP) through virtual gateways [3][9]. The limitation of doing activities outside the classroom is not an excuse because teachers can take students to visit certain locations in addition to making explorations take a closer look at learning subjects through interactive AR applications developed. By integrating AR into the wood carving art, the tool can be used by teachers or by students learning on their own for better understanding and knowledge.

The research contribution is to highlight the application of AR to support distance learning in the Covid19 epidemic situation, specializing in Wood Carving Art for the subject of Visual Arts Education Form 4. This research consists of developing AR applications, testing in the students of the subject of Visual Arts Education Form 4, and investigating the effectiveness of the developed application.

\section{LITERATURE REVIEW}

\subsection{Types of Augmented Reality}

Augmented Reality (AR) has captured the attention of people by exposing the ability to seamlessly integrate digital content with the real-world environment [12]. These digital contents enhance the understanding and imagination of an object [13]. Augmented Reality helps visualize images in a variety of forms, including animations and motion graphics, sounds, and buttons.

The four types of Augmented Reality are Marker-Based Augmented Reality, Marker-less Augmented Reality, Projection Augmented Reality, and Superimposition Based Augmented Reality [14].

1. Marker-Based Augmented Reality, also known as recognition, will detect objects in front of the camera and reflect objects on the screen. Each approach is flexible, which allows viewing from different angles and directions [15][16].

2. Marker Less Augmented Reality is one of the easiest and trending techniques. The use of Marker Less Augmented Reality is for location detection [17]. Almost all smartphone users have used it.

3. Projection-Based Augmented Reality is a type of AR that reflects light on the surface. No specific device is required except the projector [18][19].

4. Superimposition-based Augmented Reality is an AR technique that takes into account images with realistic objects. This approach involves imagination and creativity [20][21].

\subsection{Augmented Reality Development Tools}

AR development tools and platforms are widely available today. One of the good Software Development Kit (SDK) is Vuforia. Vuforia provides an excellent framework for AR development [6][7][14]. Dominant functionalities come up with text recognition and 2-Dimensional and 3-Dimensional acknowledgments. Besides that, the barcodes scanner contains data and acts as markers to detect objects. Video playback facilities upon request and virtual buttons for surface change into a touch screen. Data were able to store in the cloud or on-device storage. Four major supported platforms are android studio, IOS, Universe Window Platform, and Unity development.

The second top notable SDK to create Augmented Reality based applications is Wikitude. The previous function of Wikitude allows the creation of applications for smart glasses, and information can be stored in the cloud or on the device. Wikitude has a special attribute of providing location-based services such as Google Maps, GPS, and live location updates [6]. Wikitude makes use of JAVASCRIPT API, NATIVE API, 
CORDOVA, Unity 3D for development. Besides that, employ objects, image recognition, and manipulate virtual objects. Three major supported platforms are android studio, IOS, Microsoft Surface development.

AR Kit can identify the measurement of surroundings. Support 2Dimensional and 3Dimensional image detection and tracking surface to place objects [4][5]. AR Kit specializes in creating multiplayer Augmented Reality games, easy to detect horizontal planes detection, and facial track as well. The only platform AR Kit supports the IOS 11plus application, and it costs free.

The last top four Software Development Kit is MAXST. Primary functionalities are tracking surroundings and mapping the environment. Enable to scan barcodes and quick response (QR). Essential's characteristics can track multiple targets at a time, reduce time-consuming and finish tasks earlier than expected. MAXST also provides an occlusion effect to view virtual screen objects by real fully. Four major supported platforms are android studio, IOS, Universe Window Platform, and Unity development.

\subsection{Augmented Reality in Education}

AR technologies enable users to experience scientific phenomena that are not possible in the real world, such as certain chemical reactions, make subject matter inaccessible to students [22]. The manipulation of virtual objects and observation of phenomena that are difficult to observe in the real world can be facilitated through AR [1]. Like said, AR contributes a huge part to education.

By looking at the current situation, the covid-19 pandemic affects education in unexpected ways and to overcome the problems experienced by a teacher. AR is used as a knowledge transmitter tool [23].

\subsection{Word Carving Arts in Visual Arts Education}

The objectives of Visual Arts education are to form the personality of the Malaysian generation that is culturally literate, has high aesthetic values, imaginative, critical, creative, innovative, and inventive. The content of the curriculum can help students increase their gratitude to God, appreciate the beauty of the environment, the beauty of art, and the heritage of the nation, and can contribute towards the development of self, society, and country, in line with the aspirations of the National Education Philosophy [24]. Visual arts education expresses art creativity in carving form. Visual Arts Education is a mandatory subject for primary school students; meanwhile, for secondary students is compulsory to take from Form 1 to Form 3.

The Curriculum and Assessment Standard Document (DSKP) document contains the syllabus of Integrated Curriculum Secondary School (KBSM). This document includes four main components, namely Content Standards, Learning Standards, Suggested Activities, and Mastery Levels [24]. Meanwhile, learning standards are learning quality based, and evaluation examination marks are considerable. Suggested activities and mastery levels are to enhance students' skills and strength for a better outcome [25].

Wood Carving Arts belongs to infinite examples such as line, flower, architecture, color, space, and texture [26]. Besides that, art has the power to express emotions and ideas in attractive aspects [27]. The perception of learning art is to evolve students' knowledge and awareness in visual arts education. This encourages students to be creative and innovative in arts. Arts exploration allows students to explore deeply about arts and its heritage. In a nutshell, exploring intensively Visual Arts Education helps students be innovative and visionary [24].

\subsection{Instructional System Design Model}

In the level of learning and development material design, systematics as a procedural aspect of the system approach has been realized in many methodology practices for the design and development of the text, computer-based learning materials, and even audiovisual materials. It is called the Instructional System Design (ISD) Model.

The selection of models for learning is based on the consideration that the model is developed systematically and based on the theoretical foundation of learning design. The learning model must be prepared programmatically with systematic sequences of activities in an effort to solve learning problems related to learning resources that suit the needs and characteristics of learners. One of the ISD models that is suitable with AR for Education is ADDIE Model [28]. Fig. 1 shows the diagram of the ADDIE Model.

The ADDIE model is the finest example of the ISD Model. ADDIE's name is derived from its phase such as Analyze, Design, Development, Implementations, and Evaluations [29]. The ADDIE model depends on each stage performed in the given order. However, with a focus on reflection and literacy. This model provides an approach that focuses on providing feedback for continuous improvement. 


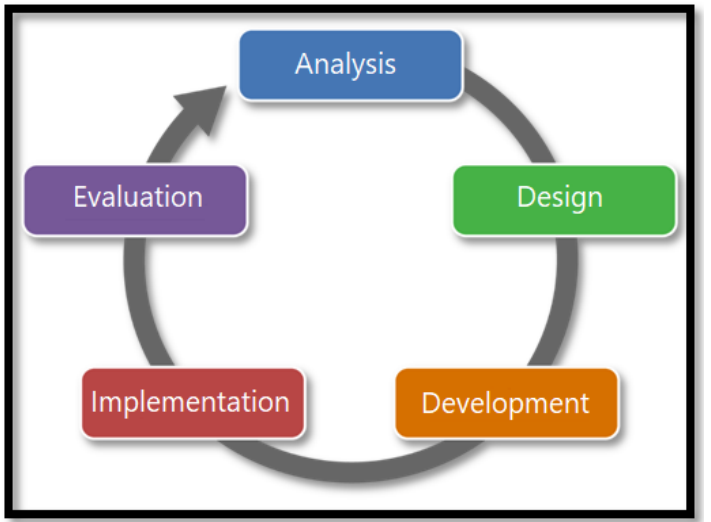

Fig 1. ADDIE Model

\section{RESEARCH METHOD}

This session discusses the chosen methodology for completing research with appropriate formulas and practices. It includes hardware and software specifications, as well as research instruments used for the development process.

Fig. 2 shows the research framework used. The first stage is the preliminary analysis. At this stage, the analysis is based on the reading and analysis of previous studies related to the integration of computer-based technologies such as courseware and AR in the field of teaching and learning processes. Phase 2 involves the process of developing AR Wood Carving as a tool by applying the ADDIE model. The data collected from the analysis is used to design and build AR content using the existing platform. The final stage involves conducting the research and evaluation in terms of usefulness.

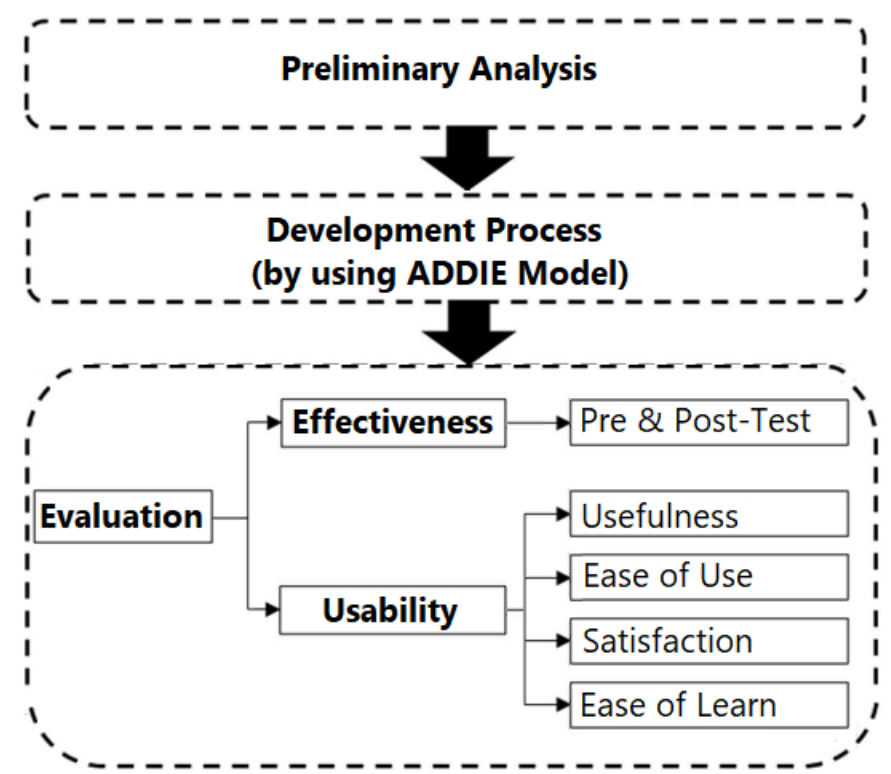

Fig 2. Research Framework

The final step of this research is evaluation. There are two evaluations carried out, namely effectiveness and usability. Usability testing is carried out to find out how easily a product can be used by certain users to achieve certain goals effectively, efficiently, and obtain satisfaction in the context of its use [30]. To measure usability, an instrument called USE (Usefulness, Satisfaction, and Ease of Use) is used. The form of the USE questionnaire consists of Usefulness, Ease of Use, Satisfaction, and Ease of Learning. In this research, usability evaluation was carried out to find out how the usefulness of Wood Carving Art AR mobile.

\subsection{Software}

The three basic software used in the development of Augmented Reality applications are Unity 3Dimensional, Vuforia SDK, and Android Software Development Kit (SDK) [6][14][30][31][32]: 
1. Unity $3 D$

Unity 3-Dimensional is the world's best real-time development platform with a robust ecosystem designed to enable system success. Unity supports various platforms such as IOS, Android, Windows, and Xbox One. Unity is part of an integrated development environment (IDE) where users can use easy programming languages such as C and JavaScript. In Wood Carving Art AR mobile application development, Unity will be useful to design and create 3-Dimensional art images for a technique of wood carving art [14][31].

\section{Vuforia SDK}

Vuforia is an Augmented Reality Software Development Kit (SDK) for mobile devices that tend to create Augmented Reality Applications. Vuforia also allows storing data, function as a database for the application. In AR Wood Carving Art mobile application development, Vuforia has functions such as tracing the image, providing different adjustment angles of the image, and allowing the creation of objects in different perspectives [6].

\section{Android SDK}

Android Software Development Kit allows developers to develop applications fast and easily. One of the best developing tools for building market-leading applications and accelerating performance. Examples of development tools are debugger, emulator, libraries, and documentation. All types of smart devices support android studio-developed applications. In AR Wood Carving Art mobile application development, Android SDK is important to center 3-Drawing and build a user-friendly application [30][32].

\subsection{Hardware}

Hardware is essential to run the program. In developing the AR Wood Carving Art mobile application, a personal computer with an operating system that supports android use is required. A computer with the Windows 10.1 operating system that supports the Intel Inside processor and 8 GB of RAM is required for 3Dimensional image processing. In addition, a webcam is required for tagging purposes.

\subsection{Research Instrument}

Gather basic functional requirements are essential to build a satisfactory and effective application. Two instrumental tools used in AR Wood Carving are a google form-based questionnaire and a semi-structured interview session. The questionnaire is based on closed-ended questions to collect the necessary information. The questionnaire was modified from Panessai [30].

The questionnaire aims to understand user expectations and needs in the application. The questionnaire was conducted at SMK Pasir Gudang (Johor), and overall, 27 students answered the questionnaire. Carrying out the checklist method helps to identify missed tasks in development and evaluate the process.

In addition, the interview session was conducted with an asynchronous approach with the teacher in charge. This interview session lasts for one week to collect all the important information to develop the system.

\subsection{Developing the AR Wood Carving Art Mobile Application}

To design the content, a developer used essential information that was gathered related to the instructional and content of the topic of wood carving art. Developer drafting and prepare the storyboard and interface for wood carving art in Visual Arts subject for Form 4. In addition, the developer drafting a mobile application flowchart involving marker-based image targets and prepare 3D models of AR Wood Carving Art mobile application images.

The detail of the flowchart used in developing the AR Wood Carving Art mobile application is shown in Fig. 3. The figure illustrates that the developer starts by selecting the appropriate topic on wood carving art in visual arts education at Form 4 . The developer has determined subtopics of craft techniques such as:

- Ukiran laying

- Ukiran Tebuk Timbul Bersilat

- Ukiran Tebuk Timbul Tanpa Silat

- Ukiran Tebuk Tembus Bersilat

- Ukiran Tebuk Tanpa Tembus Silat.

Besides that, the developer designs the image target by using Canva and transforms it into Photoshop to change the format into JPEG, and the 3-Dimensional object is created through a vectorizer using Inkscape and converted to SVG file format. Then use Blender to create a 3-Dimensional fbx file format and add assets into Unity. 


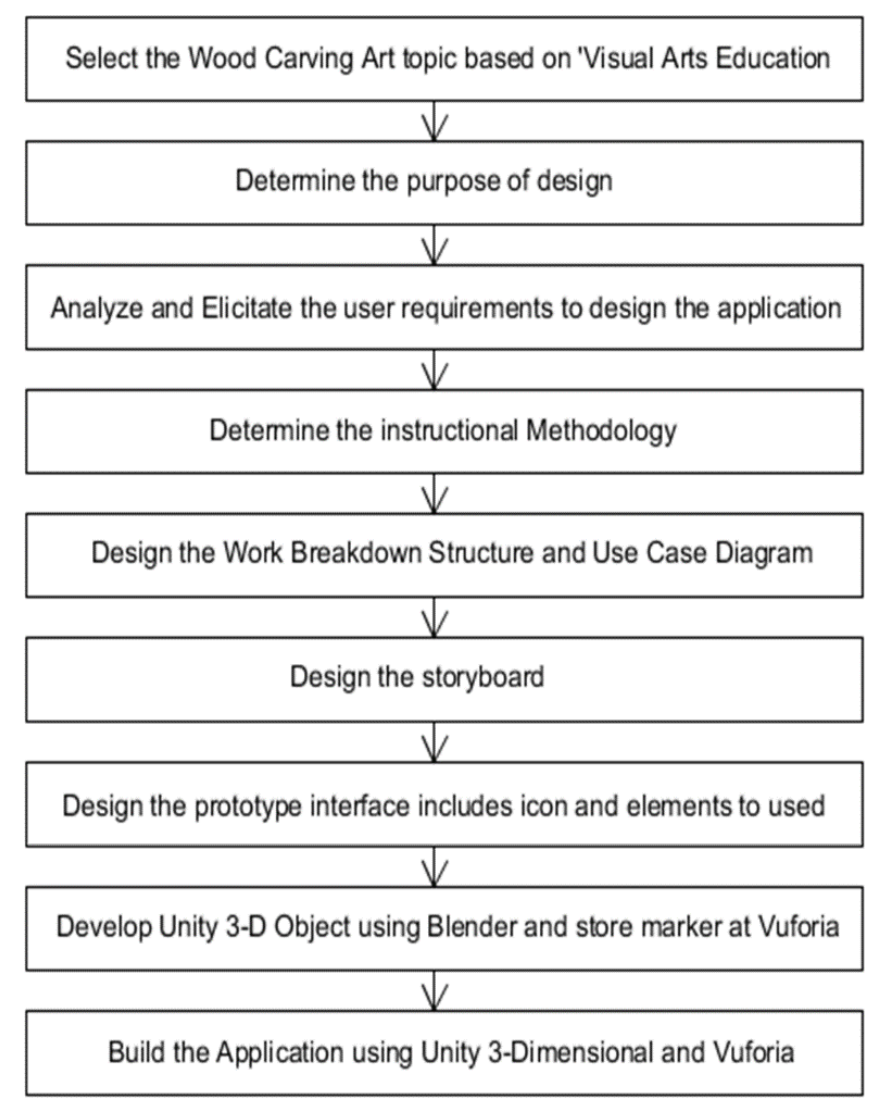

Fig 3. Flowchart for AR Wood Carving Art mobile application development

\section{RESULT AND ANALYSIS}

This session shows the result and analysis of the application of the AR Wood Carving Art mobile application. The AR Wood Carving Art mobile application was evaluated among 27 students (total of a number of students registered to Visual Arts subject) from 4 of SMK Pasir Gudang (Johor).

\subsection{Result}

The prepared questionnaire was based on usefulness to measure the usability of the AR Wood Carving Art mobile application. Fig. 4 shows the display of the AR Wood Carving Art mobile application, while the questionnaire measures are shown in Table 1.

Table 1. Result Taken from the Questionnaire

\begin{tabular}{|c|c|c|c|c|c|c|c|}
\hline & & $\mathbf{1}$ & 2 & 3 & 4 & 5 & SUM \\
\hline \multicolumn{8}{|c|}{ USEFULNESS } \\
\hline Q-A1 & AR Wood Craving Art application helps me be more effective & 0 & 0 & 0 & 5 & 22 & 27 \\
\hline Q-A2 & AR Wood Craving Art application helps me be more productive. & 0 & 0 & 0 & 5 & 22 & 27 \\
\hline Q-A3 & AR Wood Craving Art application is useful. & 0 & 0 & 0 & 5 & 22 & 27 \\
\hline Q-A4 & $\begin{array}{l}\text { AR Wood Craving Art application gives me idea of being creative } \\
\text { and innovative. }\end{array}$ & 0 & 0 & 0 & 5 & 22 & 27 \\
\hline Q-A5 & $\begin{array}{l}\text { AR Wood Craving Art application makes the things I want to } \\
\text { accomplish easier to get done. }\end{array}$ & 0 & 0 & 0 & 0 & 27 & 27 \\
\hline Q-A6 & AR Wood Craving Art application saves me time when I use it. & 0 & 0 & 0 & 5 & 22 & 27 \\
\hline Q-A7 & AR Wood Craving Art application meets my needs. & 0 & 0 & 0 & 5 & 22 & 27 \\
\hline Q-A8 & $\begin{array}{l}\text { AR Wood Craving Art application does everything I would expect } \\
\text { it to do. }\end{array}$ & 0 & 0 & 0 & 0 & 27 & 27 \\
\hline
\end{tabular}




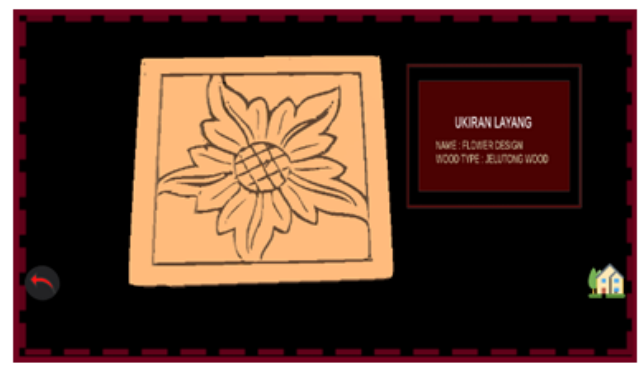

(a)

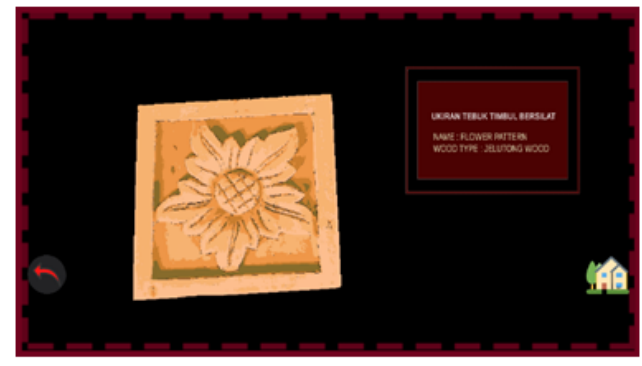

(b)

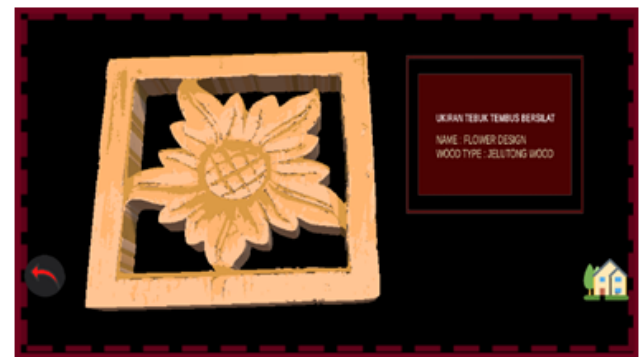

(d)

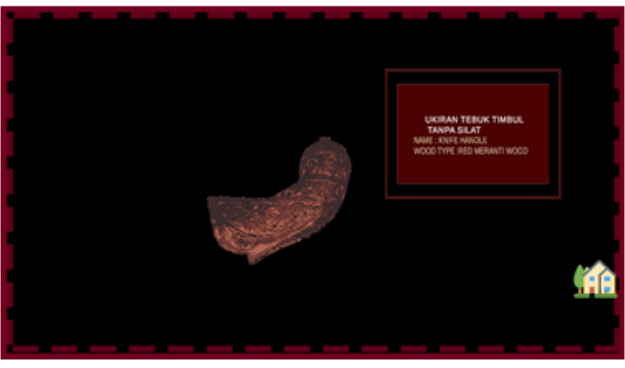

(c)

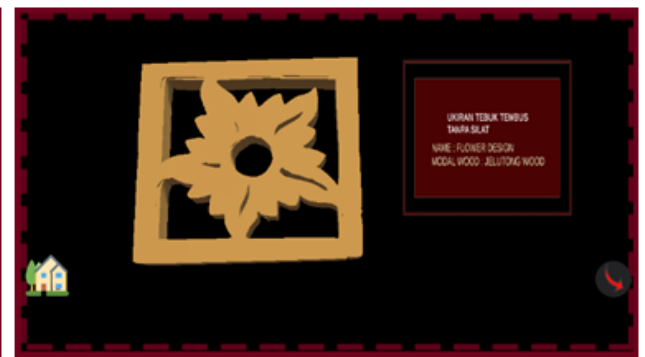

(e)

Fig 4. AR Wood Carving Art mobile application: (a) Ukiran Layang (b) Ukiran Tebuk Timbul Bersilat (c) Ukiran Tebuk Timbul Tanpa Silat (d) Ukiran Tebuk Tembus Bersilat (e) Ukiran Tebuk Tembus Tanpa Silat

\subsection{Analysis}

This phase helps gather elements that need to be added in the future for better performance. The questionnaire consists of eight questions that have been evaluated by the respondents. Fig. 5 shows the respondent's feedback for usefulness.

Q-A1 questions about the AR Wood Craving Art application help respondents to be more effective, where $80 \%$ of respondents strongly agree, and twenty percent of respondents agree. Meanwhile, Q-A2 questions about the Wood Craving Art AR application statement help users to be more productive, where eighty of respondents strongly agree, and twenty percent of respondents agree. Question Q-A4 is a statement from the Wood Craving Art AR application giving ideas to users to be creative and innovative. At this point, eighty percent of respondents strongly agree, and twenty percent of respondents agree with this point.

Q-A5 questions about the AR Wood Craving Art application make the things users want to achieve easier to do, and $100 \%$ of respondents strongly agree. Question Q-A8 is a statement that the Wood Craving Art AR app does everything the user expects it to do. One hundred percent of respondents strongly agree.

Question Q-A3 is related to the statement that the AR Wood Craving Art application is useful. 80\% of respondents strongly agree, and twenty of the respondents agree. Question Q-A6 is about the statement that the AR Wood Craving Art application saves time when users use it, and eighty percent of respondents strongly agree, 20\% of respondents agree. While Question Q-A7 related to the AR Wood Craving Art application statement that meets user needs and $80 \%$ of respondents strongly agree, twenty percent of respondents agree. 


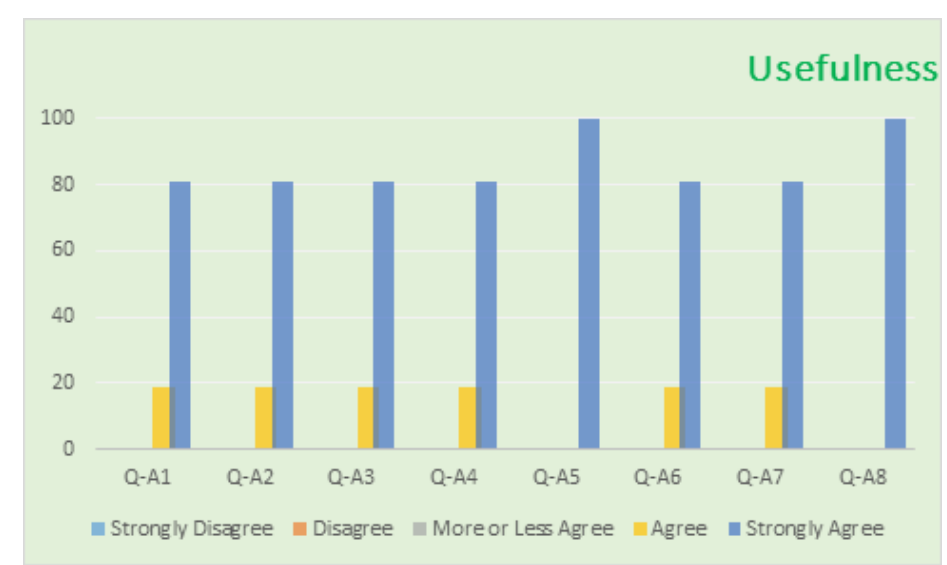

Fig 5. Respondent's Feedback: Usefulness

On average, $80 \%$ of respondents strongly agree with the question about the usefulness of the AR Wood Craving Art mobile application. Respondents think that the AR Wood Craving Art mobile application is effectively used in learning which makes users more productive, creative, and innovative. All respondents feel that the AR Wood Craving Art mobile application makes it easy for users to understand wood carving materials in fine arts subjects, and users can carry out educational and teaching activities like in a classroom.

\section{CONCLUSION}

This research extends the understanding of how creative and innovative technology has integrated with education and helps to facilitate the learning process. The existence of the AR Wood Carving Art mobile application can meet the needs of modern technology and accurate information, as well as useful skills and critical thinking. The development of interactive applications is also in line with the Cross-Curricular Elements (CCE) through the application of science and technology elements as well as creativity and innovation. Based on the usefulness evaluation, it can be concluded that the AR Wood Craving Art mobile application is effectively used in learning so that users become more productive, creative, and innovative. In addition, the AR Wood Craving Art mobile application makes it easy for users to understand wood carving materials in visual arts subjects, and users can carry out educational and teaching activities like in a classroom.

\section{REFERENCES}

[1] T. Khan, K. Johnston, dan J. Ophoff, "The Impact of an augmented reality application on learning motivation of students," in AHCI, vol. 19, no. 1, pp. 1-14, 2019. https://doi.org/10.1155/2019/7208494

[2] H. Köse, dan N. Güner-Yildiz, " Augmented Reality (AR) as a Learning Material in Special Needs Education," in EIT, vol. 26, no. 1, h. 1921-1936, 2021. http://dx.doi.org/10.1007/s10639-020-10326-w

[3] A. Theodoropoulos, dan G. Lepouras, "Augmented Reality and Programming Education: A systematic review," in IJCCI, vol. 10, 2021. https://doi.org/10.1016/j.ijcci.2021.100335

[4] W. A. N. Wan Idris, H. Halim, dan H. Hassan, "GENIUS KIDS: Learn to Count through Games", in International Journal of Multimedia and Recent Innovation, vol. 1, no. 1, pp. 1-17, 2019. https://doi.org/10.36079/lamintang.ijmari-0101.71

[5] H. Halim, W. A. N. Wan Idris, H. Hassan, and I. Y. Panessai, "Learning Logic Gate through 7-Gates", in International Journal of Multimedia and Recent Innovation, vol. 2, no. 1, pp. 1-10, 2020. https://doi.org/10.36079/lamintang.ijmari-0201.70

[6] M. A. Ishak, M. R, Kosnan, and N. F. Zakaria, "Build IoT through Virtual Reality", in International Journal of Multimedia and Recent Innovation, vol. 2, no. 1, pp. 11-25, 2020. https://doi.org/10.36079/lamintang.ijmari-0201.80

[7] A. Z. Zakaria, H. Hassan, H. Halim, W. A. N. Wan Idris, M. A. Abdullah Zawawi, and N. F. Mansor, "Learning Mathematics: One Minute”, in International Journal of Multimedia and Recent Innovation, vol. 2, no. 2, pp. 76-86, 2020. https://doi.org/10.36079/lamintang.ijmari-0202.130

[8] D. Roopa, R. Prabha, and G. A. Senthil, "Revolutionizing education system with interactive augmented reality for quality education," 2020 3rd International Conference on Materials, Manufacturing and Mechanical Engineering for Sustainable Developments-2020 (ICMSD), Chennai (India), 13-14 August 2020. https://doi.org/10.1016/j.matpr.2021.02.294

[9] H. J. Kim and S. Lee, "Examining the Role of Engaging in Research Activities with Digital Technologies for Graduate Students' Success," in IJETL, vol. 16, no. 4, pp. 212-227, 2021. https://doi.org/10.3991/ijet.v16i04.18045

[10] A. Lumbe, R. V. Mangizvo, and C. Mushaka, "Feasibility of Total Migration to Online Learning in Zimbabwe Open University: The Case of Gokwe North District Centre," in IJREHC, vol. 2, no. 2, pp. 85-99, 2021. http://www.ijrehc.com/doc/ijrehc02_14.pdf 
[11] S. Shorbagi, N. Sulaiman, A. Hasswan, M. Kaouas, M. M. Al-Dijani, R. A. El-hussein, M. T. Daghistani, S. Nugud, and S. Y. Guraya, "Evaluating the feasibility and effectiveness of e-OSCE in the COVID-19 Era," in researchsquare, pp. 1-21, 2021. https://doi.org/10.21203/rs.3.rs-506145/v1

[12] J. B. Barhorst, G. McLean, E. Shah, and R. Mack, "Blending the real world and the virtual world: Exploring the role of flow in augmented reality experiences," in Journal of Business Research, vol. 122, pp. 423-436, 2021. https://doi.org/10.1016/j.jbusres.2020.08.041

[13] P. A. Rauschnabel, "Augmented reality is eating the real-world! The substitution of physical products by holograms," in International Journal of Information, vol. 57, pp. 268-4012, 2020. https://doi.org/10.101 6/j.ijinfomgt.2020

[14] N. A. N. Ibharim, S. Z. Ramli, S. A. Zahari, N. A. A. Edyanto, and M. A. Abdullah Zawawi, "Learning History Using Augmented Reality," in International Journal of Multimedia and Recent Innovation, vol. 3, no. 1, pp. 1-10, 2021. https://doi.org/10.36079/lamintang.ijmari-0301.199

[15] B. Liu, and J. Tanaka, "Virtual Marker Technique to Enhance User Interactions in a Marker-Based AR System," in Applied Sciences, 2021. https://doi.org/10.3390/app11104379

[16] I. A. A. Putra, and I. G. N. A. C. Putra, "Development of Augmented Reality Application for Canang Education Using Marker-Based Tracking Method,” in Jurnal Elektronik Ilmu Komputer Udayana, vol. 9, no. 3, pp. 365-274, 2021. https://doi.org/10.24843/JLK.2021.v09.i03.p07

[17] N. Golse, P. Petit, M. Lewin, E. Vibert, and S. Cotin, “Augmented Reality during Open Liver Surgery Using a Markerless Non-rigid Registration System," in Journal of Gastrointestinal Surgery, vol. 25, pp. 662-671, 2020. https://doi.org/10.1007/s11605-020-04519-4

[18] A. Elsharkawy, K. Naheem, D. Koo, and M. S. Kim, "A UWB-Driven Self-Actuated Projector Platform for Interactive Augmented Reality Applications," in Applied Sciences, vol. 11, no. 6, 2021. https://doi.org10.3390/app11062871

[19] A. Gomes, K. Fernandes, and D. Wang, "Surface Prediction for Spatial Augmented Reality Applications," in Virtual Reality, 2021. https://doi.org/10.1007/s10055-020-00490-2

[20] R. K. Gupta, Augmented Reality Based Collaborative Product Enhancement. Springer, 2021.

[21] R. Romli, M. A. Aznan, L. Z. Xian, A. A. Bakhoruddin, F. N. H. Mohd Wazir, and A. R. S. Gurdial Singh, “AR@UNIMAP: A Development of Interactive Map Using Augmented Reality," in Journal of Physics: Conference Series, vol. 1755, 2020. https://doi.org/10.1088/1742-6596/1755/1/012052

[22] S. N. S. Abu Samah, "The Efficacy of Augmented Reality on Student Achievement and Perception among Teluk Intan Community College Student in Learning 3D Animation," in International Journal of Multimedia and Recent Innovation, vol. 2, no. 2, pp. 87-95, 2020. https://doi.org/10.36079/lamintang.ijmari-0202.131

[23] N. A.Atikah, S. Z. Ramli, N. A. A. Ibharim, S. A. Zahari, and M. A. A. Zawawi, "Learn Idioms Using Augmented Reality," in International Journal of Multimedia and Recent Innovation, vol. 3, no. 1, pp. 11-16, 2021. https://doi.org/10.36079/lamintang.ijmari-0301.209

[24] Kementerian Pendidikan Malaysia. Sukatan Pelajaran Kurikulum Bersepadu Sekolah Menengah: Pendidikan Seni Visual. Kuala Lumpur: Pusat Pembangungan Kurikulum KPM, 2020.

[25] R. M. Rabori, B. Bagherian, and M. Nematollahi, "Simulation-Based Mastery Improves Nursing Skills in BSc Nursing Students: A Quasi-Experimental Study," in BMC Nursing, vol. 20, no. 10, 2021. https://doi.org/10.1186/s12912-020-00532-9

[26] N. I. M. K. Daud, E. Arbi, and M. Faizal, "Pengaplikasian Ukiran Kayu Melayu Dalam Seni Bina di Malaysia," in Journal of Design and Built Environment, vol. no. 11, pp. 1-14, 2012. https://fliphtml5.com/jajj/dwup/basic

[27] G. Chilton, N. Gerber, A. Bechtel, T. Councill, M. Dreyer, and E. Yingling, "The Art of Positive Emotions: Expressing Positive Emotions within the Intersubjective Art Making Process," in Canadian Art Therapy Association Journal, vol. 28, no. 1, 2015. https://doi.org/10.1080/08322473. 2015.1100580

[28] D. D. Pradipta, Madlazim, E. Hariyono, "The Effectiveness of Science Learning Tools Based on Education Sustainable Development (ESD) to Improve Problem-Solving Skills," in International Journal of Recent Education Research, vol. 2, no. 3, 2021. https://doi.org/doi.org/10.46245/ijorer. v2i3.113

[29] H. N. Fatiyah, Riandi, and R. Solihat, "Development of learning tools education for sustainable development (ESD) integrated problem-solving for high school," in Journal of ICMScE, vol. 1806, 2020. https://10.1088/17426596/1806/1/012157

[30] I. Y. Panessai, N. Iksan, S. A. Zahari, A. S. Abdulbaqi, M. M. Lakulu, M. R. Husin, H. Ahmad, H. AbdArif and Pratiwi, "Learning Internet of Things by using Augmented Reality," 2021 5th International Conference on Virtual and Augmented Reality Simulations, Melbourne (Australia), March 2021. https://camps.aptaracorp.com/AuthorDashboard/dashboard.html?key=0\&val=dca52048-c229-11eb-8d84$166 \mathrm{a} 08 \mathrm{e} 17233$

[31] S. F. Sezali, A. M. Radzuan, N. I. MohdShabudin, and R. A. Afendi, "POCKET MALAYSIA: Learning About States in Malaysia Using Augmented Reality," in International Journal of Multimedia and Recent Innovation, vol. 2, no. 1, pp. 45-59, 2020. https://doi.org/10.36079/lamintang.ijmari-0201.82

[32] Z. Zainal Abidin, and M. A. Abdullah Zawawi, "OOP-AR: Learn Object Oriented Programming Using Augmented Reality", in International Journal of Multimedia and Recent Innovation, vol. 2, no. 1, pp. 60-75, 2020. https://doi.org/10.36079/lamintang.ijmari-0201.83 